Sains Malaysiana 47(12)(2018): 3077-3084

http://dx.doi.org/10.17576/jsm-2018-4712-18

\title{
Current Progress in Production of Flavonoids using Systems and Synthetic Biology Platforms
}

(Kajian Semasa dalam Penghasilan Flavonoid menggunakan Teknik Biologi Sistem dan Biologi Sintetik)

\author{
Ku Nurul Aqmar Ku Bahaudin, Suriana SAbri, Ahmad Bazli Ramzi, AdAm Leow Thean Chor, \\ TEWIN TENCOMNAO \& SYARUL NATAQAIN BAHARUM*
}

\begin{abstract}
Flavonoid is an industrially-important compound due to its high pharmaceutical and cosmeceutical values. However, conventional methods in extracting and synthesizing flavonoids are costly, laborious and not sustainable due to small amount of natural flavonoids, large amounts of chemicals and space used. Biotechnological production of flavonoids represents a viable and sustainable route especially through the use of metabolic engineering strategies in microbial production hosts. In this review, we will highlight recent strategies for the improving the production of flavonoids using synthetic biology approaches in particular the innovative strategies of genetically-encoded biosensors for in vivo metabolite analysis and high-throughput screening methods using fluorescence-activated cell sorting (FACS). Implementation of transcription factor based-biosensor for microbial flavonoid production and integration of systems and synthetic biology approaches for natural product development will also be discussed.
\end{abstract}

Keywords: Biosensor; flavonoid; metabolic engineering; microbial systems; synthetic biology

ABSTRAK

Flavonoid merupakan sebatian penting secara industri disebabkan oleh permintaannya yang tinggi dalam farmaseutik dan mempunyai nilai kosmeseutik. Walau bagaimanapun, kebiasaannya kaedah pengekstrakan dan sintesis flavonoid adalah berkos tinggi, rumit dan tidak mapan disebabkan oleh penghasilan flavonoid semula jadi yang rendah. Selain itu, kaedah ini juga menggunakan ruang makmal yang besar dan bahan kimia dalam kuantiti yang banyak. Hasil pengeluaran bioteknologi daripada flavonoid menunjukkan berdaya maju dan laluan yang mapan. Ini dapat dilihat melalui pelbagai kaedah yang digunakan di dalam kejuruteraan metabolisme dan biologi sintetik dengan menggunakan mikrob sebagai hos bagi pengeluaran hasil produk. Di dalam ulasan kajian ini, kami akan mengetengahkan kaedah bagi meningkatkan penghasilan flavonoid menggunakan teknik biologi sintetik. Melalui kaedah ini, teknik biosensor berasaskan pengekod genetik yang digunakan bagi menganalisis metabolit secara in vivo dan kaedah saringan daya pemprosesan tinggi berasaskan pengisihan sel teraktif berpendarfluor (FACS). Oleh yang demikian, penggunaan bioteknologi terhadap penghasilan flavonoid pada masa kini menggunakan pendekatan integrasi antara biologi sistem dan biologi sintetik bagi perkembangan produk semula jadi akan dibincangkan dengan lebih lanjut.

Kata kunci: Biologi sintetik; biosensor; flavonoid; kejuruteraan metabolisme; sistem mikrob

\section{INTRODUCTION}

\section{BIOTECHNOLOGICAL USES OF FLAVONOIDS}

Flavonoid is a C-15 molecule can be found in the form of glycosides and acylglycosides in fruits and vegetables. Flavonoid compound are naturally found in plant and have been reported in medicinal plantsimportant Moringa oleifera (Ezhilarasi et al. 2016), Eurycoma longifolia (Mohamed et al.2015), Orthosiphon stamineus (Pariyani et al.2017), Andrographis paniculata (Triantafyllidi et al.2015), and Polygonum minus (Ahmad et al. 2018; Khairudin et al. 2014; Rusdi et al. 2016). In phenylpropanoid pathway, phenylalanine ammonia-lyase (PAL) deaminates L-phenylalanine to yield cinnamic acid that serves as a substrate for hydroxylation reaction to p-coumaric acid by cinnamic-4-hydroxylase $(\mathrm{C} 4 \mathrm{H})$ aided by electron transfer partner cytochrome p450 reductase (CPR). Then, $p$-coumaric acid is sequentially converted to naringenin chalcone, the flavonoid precursor via the activities p-coumaryl CoA producing 4-coumarate: Coenzyme A ligase (4CL) and chalcone synthase (CHS), respectively, that catalyzes the stepwise condensation of three acetate units from malonyl-CoA with 4-coumarylCoA. Naringenin chalcone is isomerized by chalcone isomerase (CHI) to naringenin flavone that will be further modified by hydroxylation, glycosylation, methylation and prenylation reaction in a variety compounds. Flavonoids play important roles in plants such as act as a signal molecule in plant-microorganism symbiosis. Carletti et al. (2014) reported that nodule meristem formation will activate nodulation (nod) genes with presence of isoflavone that allows nitrogen fixation in 
the legume species. Beneficial effects of flavonoids on presymbiotic growth, such as spore germination, hyphal length, hyphal branching and formation of auxiliary cells and secondary spores of arbuscular mycorrhizal fungi has been studied by Scervino et al. (2005). Flavonoids can be group according to genus and/or species specific or only specific for a certain developmental stage of presymbiotic growth (Scervino et al. 2005). Another important role of flavonoid is in temperature acclimation that involves a number of physiological and biochemical changes occur as a result of temperature changes. Korn et al. (2008) reported the beneficial roles of quercetin as potent antioxidants during cold acclimation by ROS (reactive oxygen species) scavenging mechanism that corroborated with the findings by Watanabe and Ayugase (2015) on the increased antioxidant properties that reduced low-temperature-oxidative damage in spinach under winter sweet treatment.

\section{PHARMACEUTICAL AND PHARMACOLOGICAL PROPERTIES OF FLAVONOIDS}

Flavonoid market demands were valued at USD 840.2 million in 2015 and will reach above USD 1.047 billion in 2021 (Global Flavonoid Market 2016). Currently, there is a growing demand on flavonoids-based products in global pharmaceutical and cosmetic markets owing to well-known health benefits of flavonoids including antioxidant and anti-inflammatory activities. Plant secondary metabolites, including flavonoids and other phenolic compounds are reported responsible for variety pharmacological activities (Costa et al. 2016; $\mathrm{Ng}$ et al. 2015; Rasines-Perea \& Teissedre 2017). Functional hydroxyl groups in flavonoids mediate antioxidant activity by scavenging free radicals. These subgroups of flavonoid are isoflavones, flavones, flavonols, flavanones, flavanols or catechins and anthocyanins. Previous researches showed that the antimicrobial activities of flavonoids against bacterial (Djouossi et al. 2015) and viral infections (Lani et al. 2016; Lim et al. 2017). Besides that, flavonoid also acts against degenerative diseases such as cardiovascular diseases (Lovegrove et al. 2017), Alzheimer's disease (Bakhtiari et al. 2017) and cancer (Youns \& Hegazy 2017). Flavonoids has been increasingly used in skin care and cosmetic products as an ultraviolet radiation protectant (Jimtaisong 2015; Peng et al. 2015; Saewan \& Jimtaisong 2015). Ko et al. (2015) had found plasma that contain geneistein (isoflavone) correlated to decrease risk of type 2 diabetes in women. There is an association of the anti-diabetic effect of isoflavone towards their physiological changes. Naringenin, one of the most abundant and essential flavonoids found in most citrus fruits. Naringenin has been shown to play important roles in induction apoptotic cell death in cancer cells (Park et al. 2017). Interestingly, naringenin is also reported to exhibit anti-dengue virus activity by impairing the infection of four dengue virus serotypes in human cells (Frabasile et al. 2017).

\section{EXTRACTION OF FLAVONOID COMPOUNDS FROM PLANTS}

Flavonoids can be extracted via conventional and nonconventional techniques. Conventional techniques include soxhlet extraction, maceration, hydro-distillation and solvent extraction. However, there are some limitations in the conventional techniques. This include lengthy extraction time, high cost, high purity solvents requirement, evaporation of the large amount of solvents and poor extraction selectivity (de Castro \& Garcia-Ayuso 1998). In order to overcome these problems more non-conventional techniques were developed including ultrasound assisted extraction, enzyme-assisted extraction, microwaveextraction, supercritical fluid extraction and pressurized liquid extraction. For instance, ultrasound assisted extraction is usually useful when handling with thermo sensitive extraction and unstable compounds (Celli et al. 2015). This method helps in reducing the extraction temperature and amount of solvent used and also shorten the extraction time.

Sample preparation is a crucial step in extraction process of plant metabolites. Fresh sample or dried plants are being used for extraction. Drying or grinding might affect the preservation of chemical substances in the samples. Factors such as extraction procedure, solvent used and solvent ratio are a few examples that influenced quality of extracts and contents of active ingredients in plant extraction. Sharifi et al. (2017) had compared quercetin extraction from Raphanus sativus by using different methods with various solvents such as ethanol, methanol, water and chloroform. Quercetin was optimally extracted from Raphanus sativus by gently heating with 40 $\mathrm{mL}$ solvent at $35^{\circ} \mathrm{C}-40^{\circ} \mathrm{C}$ in maceration (Sharifi et al. 2017). The result showed that methanol was the best solvent as it gave highest yield of quercetin. Jovanović et al. (2017), had used three different extraction methods to extract Thymus serpyllum L. (Lamiaceae); maceration, heat-assisted and ultrasound-assisted extraction, respectively. This group reported that particle size, solid-to-solvent ratio, solvent type and extraction procedure are the other factor that may affected the extract sample. Although extraction method of flavonoids from plant is well described in the literature, this strategy is unfavourable. However, these techniques require laborious process optimization that often resulted in poor yield and productivity hence hampering further applications and commercialization.

\section{MICROBIAL CELL FACTORY FOR FLAVONOID PRODUCTION USING METABOLIC ENGINEERING STRATEGIES}

Metabolic engineering is defined as the alteration of metabolic pathways using recombinant DNA technology for overproduction of industrially-important fuels, chemicals and pharmaceutical products (Bailey 1991). This approach has widely employed in microbes as cell factory for sustainable and green practises using renewable feedstocks with low energy requirements, and low waste emission as compared to the conventional extraction practices that rely on plant quantity and 
use of arable land (Marienhagen \& Bott 2013). This approach is more suitable compared to extraction from plant and chemical synthesis of flavonoids. Metabolic engineering involved overexpression of target genes, manipulation of corresponding metabolic pathways and stoichiometric analysis that mainly aimed at increasing titer and productivity. Artificial gene cluster of flavonoids was first reported in $E$. coli for the biosynthesis of chalcone synthesis by introducing phenylalanine ammonia lyase (PAL) from yeast Rhodotorula rubra, 4-coumarate coenzyme A ligase (4CL) from actinomycete Streptomyces coelicolor and chalcone synthase (CHS) from licorice of Glycyrrhiza echinata. Two flavanones, pinocembrin and naringenin were successfully formed when PAL deaminated phenylalanine and tyrosine with the addition of two precursor, cinnamic acid and 4-coumaric acids (Hwang et al. 2003). Meanwhile, Watts et al. (2004) managed to produce high-level of naringenin in E. coli when there is no tyrosine fed in the culture medium. A modification of the acetate-acetyl-CoA-malonyl-CoA metabolic node had been performed in order to improve malonyl-CoA precursor availability in flavanoneproducing recombinant $E$. coli strains (Leonard et al. 2007). This approach targeted the multisubunit complex of acetyl-CoA carboxylase (ACC)-biotin ligase (BirA) and enzymes in acetate assimilation pathways in E. coli. The constructed strains were able to produce the highest flavonoid production for microbial production platforms. Thuan et al. (2017) had demonstrated the production of astilbin (taxifolin). Astilbin and D-glucose were produced in engineered E. coli BL21 (DE3) strain of which chromosomal glucose phosphate isomerase (pgi) and D-glucose-6-phosphate dehydrogenase ( $z w f)$ genes were knocked-out and overexpressed of rhamnose biosynthetic pathway to increase the yield (Thuan et al. 2017).

Apart from bacterial expression host, yeast is another well-established microbial platform for flavonoid production (Rodriguez et al. 2015). Saccharomyces cerevisiae is generally regarded as safe (GRAS) microorganism and well capable of performing posttranslational modifications of the eukaryotic proteins. The eukaryotic nature of yeast may facilitate functional expression of plant-derived flavonoidbiosynthetic genes due to the highly similar physical and physiological environment with the help of molecular and synthetic biology techniques. The first construction of phenylpropanoid pathway for the synthesis of naringenin is reported in yeast (Jiang et al. 2005). Jiang et al. (2015) had inserted PAL from Rhodosporidium toruloides, 4CL from Arabidopsis thaliana and CHS from Hypericum androsaemum genes under different individual GAL10 promoter. Modulation of upstream flavonoid biosynthetic pathway was carried out for the conversion of phenylpropanoid to increase flavanones yield (Yan et al. 2005). The gene cluster consist of $\mathrm{C} 4 \mathrm{H}$ from Arabidopsis thaliana, 4CL from Petroselinum crispum, CHI and CHS from Petunia $\times$ hybrid.
RECENT ADVANCEMENT IN NATURAL PRODUCT BIOSYNTHESIS USING SYSTEMS AND SYNTHETIC BIOLOGY APPROACHES

The advent of synthetic biology research area has greatly aided in advancing natural metabolite production in microbial host. Principally, synthetic biology focuses on the design and construction of new biological parts, devices and systems and re-designing of existing biological systems for useful purposes which complement and work in parallel with the industrial biotechnology centric metabolic engineering principles (Nielsen \& Keasling 2011). Metabolic engineering and synthetic biology have been instrumental for biotechnological production of natural products using existing or novel genetic toolsets and circuits in tandem with increasing use of computeraided design and automated strain screening tools. The pioneering synthetic biology works in the generation of genetic oscillator and toggle switch have contributed toward changing the dynamics in the way researchers designed and controlled genetic networks and constructs a large electronic circuits (Elowitz \& Leibler 2000; Gardner et al. 2000). Advances in genomics especially through the works of Craig Venter groups have led to the creation of synthetic minimal genome using homology-based recombination for synthesizing and joining of multiple DNA fragments in shorter amount of time (Gibson et al. 2010, 2008). The greater ability to synthesize and design biosynthesis genes and genetic circuits have brought wonders in biotechnological production of bio-based products particularly as precursor for antimalarial drugs (amorphadiene), advanced biofuels (bisabolene) and analgesics (thebaine) (Galanie et al. 2015; Martin et al. 2003; Peralta-Yahya et al. 2011). For instance, the production of antimalarial drug in engineered E. coli and $S$. cerevisiae were successfully implemented using these biotechnological methods (Martin et al. 2003; Ro et al. 2006). A more recent successful production of opioids was reported in engineered $S$. cerevisiae expressing 21 and 23 alkaloid biosynthetic genes for the production of thebaine and hydrocodone, respectively (Galanie et al. 2015). This discovery has been greatly facilitated by the rapid expansion of the existing genetic databases through the advancement of systems biology approaches particularly next generation transcriptome analysis of non-model plants and other organisms (Farrow et al. 2015; Galanie et al. 2015). Besides that, transcriptome data mining via next gene sequencing platform is one of the key strategies for discovery of novel genes and known enzymes with multiple functions in tropical and medicinal plants (Jamaluddin et al. 2017; Loke et al. 2017). In addition to transcriptomics, integrated systems biology approaches including proteomics and bioinformatics analysis have been instrumental in elucidating genetic and metabolites information of a variety of non-model plants, hence, allowing recursive data gene mining for metabolic engineering and synthetic biology applications (Diamond \& Desgagne-Penix 2015; Rai et al. 2017). 


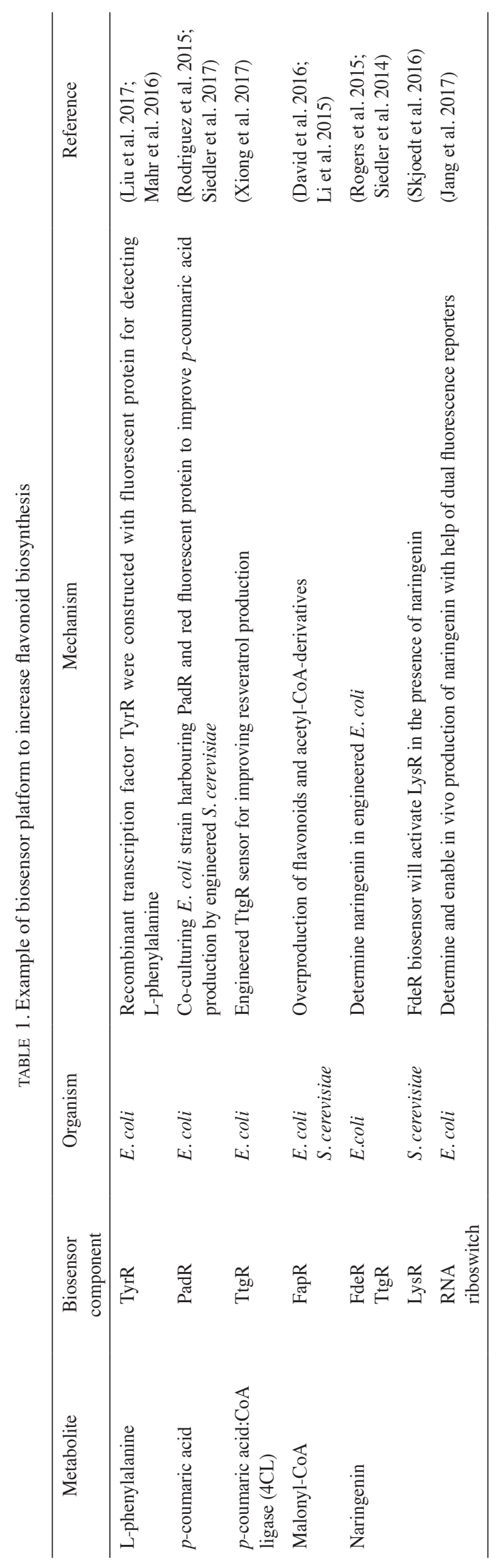


GENETICALLY-ENCODED BIOSENSOR PLATFORMS FOR IMPROVING FLAVONOID BIOSYNTHESIS

Using model microbes as chassis and production hosts, the biosynthesis of flavonoids has been improved by multiple folds via the use of synthetic biology approaches and high-throughput methods such as fluorescenceactivated cell sorting (FACS) via the combination of the flavonoid biosynthesis pathway with recombinant fluorescent proteins as transducer and reporter systems (Siedler et al. 2014). High throughput methods mainly involve the designed and construction of geneticallyencoded biosensors for detecting and reporting flavonoid compounds produced by microbes overexpressing flavonoid biosynthetic pathway. This method has enabled rapid screening and isolation of flavonoid-producing microbes without the use of conventional chromatography and enzymatic assays techniques that are costly, laborious and time-consuming (Rogers \& Church 2016; Siedler et al. 2014). The advantages of using biosensor-aided strain development have led to growing interest in implementing this strategy in metabolite analysis, product monitoring and metabolic engineering of natural products (Chou \& Keasling 2013; Liang et al. 2017; Rogers et al. 2015).

Many of the genetically-encoded biosensors involved the use of transcription factors (TFs) as metabolite responsive and sensing component of highly regulated fluorescent-producing gene expression systems (Mahr \& Frunzke 2016; Rogers et al. 2016). These TF-dependent biosensor approaches have been employed in improving intermediates and products in the flavonoid pathway which derived from L-phenylalanine or tyrosine as the entry point. Both amino acids have been explored for their conversion to $p$-coumaric acid an intermediate of the flavonoid pathway in which the tyrosine pathway did not require the expression of cytochrome-related P450 enzymes commonly found in plants (Rodriguez et al. 2017; Stahlhut et al. 2015). Table 1 shows a summary of these biosensor components to increase level of flavonoid biosynthesis in $E$. coli and yeast. In sum, the rapid development of synthetic biology will provide the ever expanding genetic tools for manipulating microbes to produce flavonoids and other natural products using sustainable and innovative approaches.

\section{CONCLUSION}

Production of flavonoids using synthetic biology represents a sustainable and cost-effective means in getting the production of that targeted plant metabolites. Plant genetic manipulations are relatively difficult and limited only to model species. Deeper understanding metabolic regulation of the desired pathways of intermediates and enzymes is needed in order to increase the desired secondary metabolite compounds. Rapid development of advanced technologies and high throughput methods has enabled greater access to the nature's genetic information hence providing well-endowed methods for natural product discovery and commercialization. Genetically-encoded biosensors represent an innovative and feasible synthetic biology approach for analysis and improvement of flavonoids in engineered microbes. Integration of systems biology and synthetic biology research fields will therefore lead to more intensive genetic discoveries and bio-product development that are crucial for greener and sustainable research and industrial practices.

\section{ACKNOWLEDGEMENTS}

This research is supported through a grant RB-2016001 (PKA0514F004) awarded to Universiti Kebangsaan Malaysia through Academy of Sciences Malaysia (ASM) Initiative by the Ministry of Science, Technology and Innovation (MOSTI), Malaysia. Ku Nurul Aqmar $\mathrm{Ku}$ Bahaudin is supported by MyBrain15 (MyPhD) scholarship from Ministry of Higher Education (MOHE), Malaysia. She also received fellowship for one semester program at Chulalongkorn University, Thailand under International Young Scientist Program.

\section{REFERENCES}

Ahmad, R., Sahidin, I., Taher, M., Low, C., Noor, N.M., Sillapachaiyaporn, C., Chuchawankul, S., Temcomnao, T., Iskandar, F., Rajab, N.F. \& Baharum, S.N. 2018. Polygonumins A, a newly isolated compound from the stem of Polygonum minus Huds with potential medicinal activities. Scientific Reports 8(1): 4202.

Bailey, J.E. 1991. Towards a science of metabolic engineering. Science 252(5013): 1668-1675.

Bakhtiari, M., Panahi, Y., Ameli, J. \& Darvishi, B. 2017. Protective effects of flavonoids against Alzheimer's disease related neural dysfunctions. Biomedicine and Pharmotherapy 93: 218-229.

Carletti, G., Nervo, G. \& Cattivelli, L. 2014. Flavonoids and melanins: A common strategy across two kingdoms. International Journal of Biological Sciences 10(10): 1159.

Celli, G.B., Ghanem, A. \& Brooks, M.S.L. 2015. Optimization of ultrasound-assisted extraction of anthocyanins from haskap berries (Lonicera caerulea $\mathrm{L}$.) using response surface methodology. Ultrasonics Sonochemistry 27: 449-455.

Chou, H.H. \& Keasling, J.D. 2013. Programming adaptive control to evolve increased metabolite production. Nature Communications 4: 2595-2603.

Costa, S.L., Silva, V.D.A., dos Santos Souza, C., Santos., C.C., Paris, I., Muñoz, P. \& Segura-Aguilar, J. 2016. Impact of plant-derived flavonoids on neurodegenerative diseases. Neurotoxicity Research 30(1): 41-52.

David, F., Nielsen, J. \& Siewers, V. 2016. Flux control at the malonyl-CoA node through hierarchical dynamic pathway regulation in Saccharomyces cerevisiae. ACS Synthetic Biology 5(3): 224-233.

De Castro, M.L. \& Garcia-Ayuso, L.E. 1998. Soxhlet extraction of solid materials: An outdated technique with a promising innovative future. Analytica Chimica Acta 369(1): 1-10.

Djouossi, M.G., Ngnokam, D., Kuiate, J.R., Tapondjou, L.A., Harakat, D. \& Voutquenne-Nazabadioko, L. 2015. Antimicrobial and antioxidant flavonoids from the leaves of Oncoba spinosa Forssk. (Salicaceae). BMC Complementary and Alternative Medicine 15(1): 134. 
Diamond, A. \& Desgagne-Penix, I. 2015. Metabolic engineering for the production of plant isoquinoline alkaloids. Plant Biotechnology Journal: 1319-1328.

Elowitz, M.B.\& Leibler, S. 2000. A synthetic oscillatory network of transcriptional regulators. Nature 403(6767): 335-338.

Ezhilarasi, A.A., Vijaya, J.J., Kaviyarasu, K., Maaza, M., Ayeshamariam, A. \& Kennedy, L.J. 2016. Green synthesis of $\mathrm{NiO}$ nanoparticles using Moringa oleifera extract and their biomedical applications: Cytotoxicity effect of nanoparticles against HT-29 cancer cells. Journal of Phytochemistry and Photobiology B: Biology 164: 352-360.

Farrow, S.C., Hagel, J.M., Beaudoin, G.A.W., Burns, D.C. \& Facchini, P.J. 2015. Stereochemical inversion of (S)-reticuline by a cytochrome P450 fusion in opium poppy. Nature Chemical Biology 11(9): 728-732.

Frabasile, S., Koishi, A.C., Kuczera, D., Silveira, G.F., Verri, W.A., Dos Santos, C.N.D. \& Bordignon, J. 2017. The citrus flavanone naringenin impairs dengue virus replication in human cells. Scientific Reports p. 7.

Galanie, S., Thodey, K., Trenchard, I.J., Filsinger Interrante, M. \& Smolke, C.D. 2015. Complete biosynthesis of opioids in yeast. Science 349(6252): 1095-1100.

Gardner,T.S., Cantor, C.R. \& Collins, J.J. 2000. Construction of a genetic toggle switch in Escherichia coli. Nature 403(6767): 339-342.

Gibson, D.G., Benders, G.A., Axelrod, K.C., Zaveri, J., Algire, M.A., Moodie, M., Montague, M.G., Venter, J.C., Smith, H.O. \& Hutchison, C.A. 2008. One-step assembly in yeast of 25 overlapping DNA fragments to form a complete synthetic Mycoplasma genitalium genome. Proceedings of the National Academy of Sciences 105(51): 20404-20409.

Gibson, D.G., Glass, J.I., Lartigue, C., Noskov, V.N., Chuang, R.Y., Algire, M.A., Benders, G.A., Montague, M.G., Ma, L., Moodie, M.M., Merryman, C., Vashee, S., Krishnakumar, R., Assad-Garcia, N., Andrews-Pfannkoch, C., Denisova, E.A., Young, L., Qi, Z.Q., Segall-Shapiro, T.H., Calvey, C.H., Parmar, P.P., Hutchison, C.A., Smith, H.O. \& Venter, J.C. 2010 . Creation of a bacterial cell controlled by a chemically synthesized genome. Science 329(5987): 52-56.

Global Flavonoids Market will reach USD 1047.63 million in 2021: Zion Market Research. (2016, December 19). Retrieved from http://www.econotimes.com/Global-FlavonoidsMarket-will-reach-USD-104763-million-in-2021-ZionMarket-Research-457514.

Hwang, E.I., Kaneko, M., Ohnishi, Y. \& Horinouchi, S. 2003. Production of plant-specific flavanones by Escherichia coli containing an artificial gene cluster. Applied and Environmental Microbiology 69(5): 2699-2706.

Jamaluddin, D., Normah, M.N. \& Goh. H.H. 2017. Transcriptome analysis of Carica papaya embryogenic callus upon Deetiolated 1 (DET1) gene suppression. Genomics Data 12: 120-121.

Jang, S., Jang, S., Xiu, Y., Kang, T.J., Lee, S.H., Koffas, M.A.G. \& Jung, G.Y. 2017. Development of artificial riboswitches for monitoring of Naringenin in vivo. ACS Synthetic Biology 6(11): 2077-2085.

Jiang,H., Wood, K.V.\& Morgan,J.A. 2005. Metabolic engineering of the phenylpropanoid pathway in Saccharomyces cerevisiae. Applied and Environmental Microbiology 71(6): 2962-2969.

Jovanović, A.A., Đorđević, V.B., Zdunić, G.M., Pljevljakušić, D.S., Šavikin, K.P., Gođevac, D.M. \& Bugarski, B.M. 2017. Optimization of the extraction process of polyphenols from Thymus serpyllum L. herb using maceration, heat-and- ultrasound-assisted techniques. Separation and Purification Technology 179: 369-380.

Khairudin, K., Sukiran, N.A., Goh, H.H., Baharum, S.N. \& Normah, M.N. 2014. Direct discrimination of different plant populations and study on temperature effects by Fourier transform infrared spectroscopy. Metabolomics 10(2): 203 211

Ko, K.P., Kim, C.S., Ahn, Y., Park, S.J., Kim, Y.J., Park, J.K., Lim, Y.K., Yoo, K.Y., Yoo, K.Y. \& Kim, S.S. 2015. Plasma isoflavone concentration is associated with decreased risk of type 2 diabetes in Korean women but not men: Results from the Korean genome and epidemiology study. Diabetologia 58: 726-735.

Korn, M., Peterek, S., Mockk, H.P., Heyer, A.G. \& Hincha, D.K. 2008. Heterosis in the freezing tolerance, and sugar and flavonoid contents of crosses between Arabidopsis thaliana accessions of widely varying freezing tolerance. Plant, Cell \& Environment 31(6): 813-827.

Lander, E.S. 2016. The heroes of CRISPR. Cell 164(1): 18-28.

Lani, R., Hassandarvish, P., Shu, M.H., Phoon, W.H., Chu, J.J.H., Higgs, S., Vandalingham, D.,Abu Bakar, S. \& Zandi, K. 2016. Antiviral activity of selected flavonoids against Chikungunya virus. Antiviral Research 133: 50-61.

Leonard, E., Lim, K.H., Saw, P.N. \& Koffas, M.A. 2007. Engineering central metabolic pathways for high-level flavonoid production in Escherichia coli. Applied and Environmental Microbiology 73(12): 3877-3886.

Li, S., Si, T., Wang, M. \& Zhao, H. 2015. Development of a synthetic malonyl-CoA sensor in Saccharomyces cerevisiae for intracellular metabolite monitoring and genetic screening. ACS Synthetic Biology 4(12): 1308-1315.

Liang, W.F., Cui, L.Y., Cui, J.Y., Yu, K.W., Yang, S., Zhang, C. \& Xing, X.H. 2017. Biosensor-assisted transcriptional regulator engineering for Methylobacterium extorquens AM1 to improve mevalonate synthesis by increasing the acetylCoA supply. Metabolic Engineering 39: 159-168.

Lim, H.J., Nguyen, T.T.H., Kim, N.M., Park, J.S., Jang, T.S. \& Kim, D. 2017. Inhibitory effects of flavonoids against NS2B-NS3 protease of ZIKA virus and their structure activity relationship. Biotechnology Letters 39(3): 415-421.

Liu, Y., Zhuang, Y., Ding, D., Xu, Y., Sun, J. \& Zhang, D. 2017. Biosensor-based evolution and elucidation of a biosynthetic pathway in Escherichia coli. ACS Synthetic Biology 6(5): 837-848.

Loke, K.K., Rahnamaie-Tajadod, R., Yeoh, C.C., Goh, H.H., Mohamed-Hussein, Z.A., Zainal, Z., Ismail, I. \& Noor, N.M. 2017. Transcriptome analysis of Polygonum minus reveals candidate genes involved in important secondary metabolic pathways of phenylpropanoids and flavonoids. PeerJ 5: e2938.

Lovegrove, J.A., Stainer, A. \& Hobbs, D.A. 2017. Role of flavonoids and nitrates in cardiovascular health. Proceedings of the Nutrition Society 76(2): 83-95.

Marienhagen, J. \& Bott, M. 2013. Metabolic engineering of microorganisms for the synthesis of plant natural products. Journal of Biotechnology 163(2): 166-178.

Mahr, R. \& Frunzke, J. 2016. Transcription factor-based biosensors in biotechnology: Current state and future prospects. Applied Microbiology and Biotechnology 100(1): 79-90.

Mahr, R., von Boeselager, R.F., Wiechert, J. \& Frunzke, J. 2016. Screening of an Escherichia coli promoter library 
for a phenylalanine biosensor. Applied Microbiology and Biotechnology 100(15): 6739-6753.

Martin, V.J.J., Piteral, D.J., Withers, S.T., Newman, J.D. \& Keasling, J.D. 2003. Engineering a mevalonate pathway in Escherichia coli for production of terpenoids. Nature Biotechnology 21(7): 796-802.

Mohamed, A.N., Vejaya, J. \& Yusoff, M.M. 2015. Review on Eurycoma longifolia pharmacological and phytochemical properties. Journal of Applied Sciences 15(6): 831.

Ng, Y.P., Or, T.C.T. \& Ip, N.Y. 2015. Plant alkaloids as drug leads for Alzheimer's disease. Neurochemistry International 89: 260-270.

Nielsen, J. \& Keasling, J.D. 2011. Synergies between synthetic biology and metabolic engineering. Nature Biotechnology 29(8): 693-695.

Pariyani, R., Ismail, I.S., Azam, A., Khatib, A., Abas, F., Shaari, K. \& Hamza, H. 2017. Urinary metabolic profiling of cisplatin nephrotoxicity and nephroprotective effects of Orthosiphon stamineus leaves elucidated by $1 \mathrm{H}$ NMR spectroscopy. Journal of Pharmaceutical and Biomedical Analysis 135: 20-30.

Park, H.J., Choi, Y.J., Lee, J.H. \& Nam, M.J. 2017. Naringenin causes ASK1-induced apoptosis via reactive oxygen species in human pancreatic cancer cells. Food and Chemical Toxicology 99: 1-8.

Peng, Y., Xuan, M., Leung, V.Y.L. \& Cheng, B. 2015. Stem cells and aberrant signalling of molecular systems in skin aging. Ageing Research Reviews 19: 8-21.

Peralta-Yahya, P.P., Ouellet, M., Chan, R., Mukhopadhyay, A., Keasling, J.D. \& Lee, T.S. 2011. Identification and microbial production of a terpene-based advanced biofuel. Nature Communications 27(2): 483-494.

Rai, A., Saito, K. \& Yamazaki, M. 2017. Integrated omics analysis of specialized metabolism in medicinal plants. Plant Journal 90(4): 764-787.

Rasines-Perea, Z. \& Teissedre, P.L. 2017. Grape polyphenols' effects in human cardiovascular diseases and diabetes. Molecules 22(1): E68.

Ro, D.K., Paradise, E.M., Ouellet, M., Fisher, K.J., Newman, K.L., Ndungu, J.M., Ho, K.A., Eachus, R.A., Ham, T.S., Kirby, J., Chang, M.C., Withers, S.T., Shiba, Y., Sarpong, R. \& Keasling, J.D. 2006. Production of the antimalarial drug precursor artemisinic acid in engineered yeast. Nature 440(7086): 940.

Rodriguez, A., Strucko, T., Stahlhut, S.G., Kristensen, M., Svenssen, D.K., Forster, J., Nielsen, J. \& Borodina, I. 2017. Metabolic engineering of yeast for fermentative production of flavonoids. Bioresource Technology 245: 1645-1654.

Rodriguez, A., Kildegaard, K.R., Li, M., Borodina, I. \& Nielsen, J. 2015. Establishment of a yeast platform strain for production of p- coumaric acid through metabolic engineering of aromatic amino acid biosynthesis. Metabolic Engineering 31: 181-188.

Rogers, J.K. \& Church, G.M. 2016. Genetically encoded sensors enable real-time observation of metabolite production. Proceedings of the National Academy of Sciences 113(9): 2388-2393.

Rogers, J.K., Taylor, N.D . \& Church, G.M. 2016. Biosensor-based engineering of biosynthetic pathways. Current Opinion in Biotechnology 42: 84-91.

Rogers, J.K., Guzman, C.D., Taylor, N.D., Raman, S., Anderson, K. \& Church, G.M. 2015. Synthetic biosensors for precise gene control and real-time monitoring of metabolites. Nucleic Acids Research 43(15): 7648-7660.
Rusdi, N.A., Goh, H.H. \& Baharum, S.N. 2016. GC-MS/ Olfactometric characterisation and aroma extraction dilution analysis of aroma active compounds in 'Polygonum minus' essential oil. Plant Omics 9(4): 289.

Saewan, N. \& Jimtaisong, A. 2015. Natural products as photoprotection. Journal of Cosmetic Dermatology 14(1): 47-63.

Scervino, J.M., Ponce, M.A., Erra-Bassells, R., Vierheilig, H., Ocampo, J.A. \& Godeas, A. 2005. Flavonoids exhibit fungal species and genus specific effects on the presymbiotic growth of Gigaspora and Glomus. Mycological Research 109(7): 789-794.

Sharifi, N., Mahernia, S. \& Amanlou, M. 2017. Comparison of different methods in quercetin extraction from leaves of Raphanus sativus L. Pharmaceutical Sciences 23(1): 59-65.

Siedler, S., Khatri, N.K., Zsohár, A., Kjærbølling, I., Vogt, M., Hammar, P., Nielsen, C.F., Mariehagen, J., Sommer, M.O.A. \& Joensson, H.N. 2017. Development of a bacterial biosensor for rapid screening of yeast p-coumaric acid production. ACS Synthetic Biology 6(10): 1860-1869.

Siedler, S., Stahlhut, S.G., Malla, S., Maury, J.Ô. \& Neves, A.R. 2014. Novel biosensors based on flavonoid-responsive transcriptional regulators introduced into Escherichia coli. Metabolic Engineering 21: 2-8.

Skjoedt, M.L., Snoek, T., Keldegaard, K.R., Arsovska, D., Eichenberger, M., Geodecke, T.J., Rajkumar, A.S., Zhang, J., Kristensen, M., Lehka, B.J., Siedler, S., Borodina, I., Jensen, M.K. \& Keasling, J.D. 2016. Engineering prokaryotic transcriptional activators as metabolite biosensors in yeast. Nature Chemical Biology 12(11): 951-958.

Stahlhut, S.G., Siedler, S., Malla, S., Harrison, S.J., Maury, J., Neves, A.R. \& Forster, J. 2015. Assembly of a novel biosynthetic pathway for production of the plant flavonoid fisetin in Escherichia coli. Metabolic Engineering 31: 84-93.

Thuan, N.H., Malla, S., Trung, N.T., Dhakal, D., Pokhrel, A.R., Chu, L.L. \& Sohng, J.K. 2017. Microbial production of astilbin, a bioactive rhamnosylated flavononol, from taxifolin. World Journal of Microbiology and Biotechnology 33(2): 36.

Triantafyllidi, A., Xanthos, T., Papalois, A. \& Triantafillidis, J.K. 2015. Herbal and plant therapy in patients with inflammatory bowel disease. Annals of Gastroenterology: Quarterly Publication of the Hellenic Society of Gastroenterology 28(2): 210.

Watanabe, M. \& Ayugase, J. 2015. Effect of low temperature on flavonoids, oxygen radical absorbance capacity values and major components of winter sweet spinach (Spinacia oleracea L.). Journal of the Science of Food and Agriculture 95(10): 2095-2104.

Watts, K.T., Lee, P.C. \& Schmidt-Dannert, C. 2004. Exploring recombinant flavonoid biosynthesis in metabolically engineered Escherichia coli. Chembiochem 5(4): 500-507.

Xiong, D., Lu, S., Wu, J., Liang, C., Wang, W., Wang, W., Jin, J.M. \& Tang, S.Y. 2017. Improving key enzyme activity in phenylropanoid pathway with a designed biosensor. Metabolic Engineering 40: 115-123.

Yan, Y., Kohli, A. \& Koffas, M.A. 2005. Biosynthesis of natural flavanones in Saccharomyces cerevisiae. Applied and Environmental Microbiology 71(9): 5610-5613.

Youns, M. \& Hegazy, W.A.H. 2017. The natural flavonoid fisetin inhibits cellular proliferation of hepatic, colorectal, and pancreatic cancer cells through modulation of multiple signalling pathway. PloS One 12(1): e0169335. 
Ku Nurul Aqmar Ku Bahaudin, Ahmad Bazli Ramzi \& Syarul Nataqain Baharum*

Institute of Systems Biology (INBIOSIS)

Universiti Kebangsaan Malaysia

43600 UKM Bangi, Selangor Darul Ehsan

Malaysia

Suriana Sabri \& Adam Leow Thean Chor

Enzyme and Microbial Technology Research Center

Faculty of Biotechnology and Biomolecular Sciences Universiti Putra Malaysia

43400 Serdang, Selangor Darul Ehsan

Malaysia

Suriana Sabri

Department of Microbiology

Faculty of Biotechnology and Biomolecular Sciences

Universiti Putra Malaysia

43400 Serdang, Selangor Darul Ehsan

Malaysia
Adam Leow Thean Chor

Department of Cell and Molecular Biology

Faculty of Biotechnology and Biomolecular Sciences

Universiti Putra Malaysia

43400 Serdang, Selangor Darul Ehsan

Malaysia

Tewin Tencomnao

Department of Clinical Chemistry

Faculty of Allied Health Sciences

Chulalongkorn University, Bangkok

Thailand

*Corresponding author; email: nataqain@ukm.edu.my

Received: 30 May 2018

Accepted: 14 September 2018 